Penentuan luas, potensi dan kesesuaian lahan tambak di Sulawesi Selatan ..... (Akhmad Mustafa)

\title{
PENENTUAN LUAS, POTENSI DAN KESESUAIAN LAHAN TAMBAK DI SULAWESI SELATAN MELALUI PEMANFAATAN DATA SATELIT PENGINDERAAN JAUH
}

\author{
Akhmad Mustafa dan Tarunamulia \\ Balai Riset Perikanan Budidaya Air Payau \\ Jl. Makmur Dg. Sitakka-Maros, Sulawesi Selatan 90511 \\ E-mail: akhmadmustafa@yahoo.com
}

\begin{abstract}
ABSTRAK
Sulawesi Selatan merupakan salah satu sentra produksi budidaya tambak dan memiliki tambak terluas di Indonesia. Selain itu, Sulawesi Selatan juga masih memiliki potensi lahan untuk pengembangannya. Sejak beberapa tahun terakhir, Balai Riset Perikanan Budidaya Air Payau telah melaksanakan berbagai kegiatan yang terkait dengan sumberdaya lahan tambak dalam upaya peningkatan produktivitas tambak yang berkelanjutan. Hasil analisis data citra satelit penginderaan jauh (inderaja) dan atau radar yang dikombinasikan dengan sistem informasi geografis telah dimanfaatkan dalam kegiatan yang berhubungan dengan sumberdaya lahan untuk budidaya tambak. Data ini dimanfaatkan dalam penentuan luas lahan tambak yang ada, potensial lahan tambak dan kesesuaiannya di beberapa kabupaten di Sulawesi Selatan.
\end{abstract}

\section{KATAKUNCl: inderaja, tambak, Sulawesi Selatan}

\section{PENDAHULUAN}

Jenis perikanan budidaya yang dilakukan di Indonesia meliputi budidaya laut, budidaya tambak (air payau), budidaya kolam, dan budidaya sawah. Di antara berbagai jenis perikanan budidaya tersebut, produksi tertinggi yaitu 559.612 ton $(38,10 \%$ dari total produksi perikanan budidaya) berasal dari tambak dengan luas mencapai 489.811 ha (luas kotor) pada tahun 2004 (Anonim, 2006). Usaha perikanan budidaya tambak merupakan kegiatan yang memanfaatkan kawasan pesisir yang mampu memberikan kontribusi cukup besar terhadap pendapatan masyarakat pesisir, penyedia lapangan kerja, dan perolehan devisa negara yang potensial. Sulawesi Selatan merupakan salah satu sentra produksi budidaya tambak dan memiliki tambak terluas di Indonesia yaitu 98.617 ha (Anonim,
2008). Selain itu, Sulawesi Selatan juga memiliki potensi lahan tambak sekitar 150.000 ha atau masih memiliki potensi lahan tambak seluas $51.383 \mathrm{ha}$.

Sejak beberapa tahun terakhir, Balai Riset Perikanan Budidaya Air Payau (BRPBAP) telah melaksanakan berbagai kegiatan yang terkait dengan sumberdaya lahan tambak dalam upaya peningkatan produktivitas tambak yang berkelanjutan. Secara umum kegiatan tersebut untuk memvalidasi luasan tambak yang ada (eksisting), menentukan potensial dan menentukan kesesuaiannya. Validasi luas tambak dilakukan sebagai upaya untuk mendapatkan data terbaru luasan tambak yang ada dan perubahan luasan secara temporal. Penentuan potensial lahan dilakukan dalam upaya penyediaan data dan informasi luas dan letak potensial lahan tambak tersebut. Kesesuaiannya ditentukan untuk mengetahui daya dukung lahan untuk budidaya.

Data penginderaan jauh (inderaja) dapat berupa foto udara, citra satelit maupun citra radar hasil pemotretan maupun scan elektronik. Teknologi inderaja melalui pemanfaatan citra satelit telah digunakan sebagai sumber data utama penggunaan lahan di seluruh dunia (Campbell, 1983 dalam Lo, 1996). Meskipun demikian, hal ini belum berlaku di Indonesia, di mana peta-peta penggunaan lahan pada tingkat kabupaten masih banyak yang dibangun berdasarkan survai terestris (Danoedero, 2004). Data dari citra satelit maupun radar ini harus diimbangi dengan pengolahan dan mengubahnya menjadi data wilayah sehingga telah dikembangkan teknologi pengolahan data wilayah yang dikenal dengan Sistem Informasi Geografis (SIG). Makalah ini memberikan gambaran mengenai pemanfaatan data citra satelit penginderaan jauh untuk budidaya tambak yang telah dilaksanakan oleh BRPBAP dengan harapan diperoleh data terkini yang dapat diletakkan dalam konteks masalah ketersediaan basis data penggunaan lahan, mengetahui kesesuaiannya untuk budidaya tambak dan dapat menjadi acuan pemerintah setempat dalam penentuan Rencana Tata Ruang Wilayah. 


\section{PENENTUAN LUASTAMBAK}

Penentuan luas tambak di Sulawesi Selatan telah dilakukan di beberapa kabupaten di Sulawesi Selatan seperti di Kabupaten Maros dan Pangkep (Mustafa et al., 2006), Pinrang (Paena et al., 2008a); Luwu Utara (Paena et al., 2008b); Barru (Tarunamulia et al., 2008). Contoh penentuan luas tambak secara temporal dicontohkan di Kabupaten Pinrang (Gambar 1).

Data utama yang digunakan dalam penentuan luas tambak di Kabupaten Pinrang adalah citra satelit dari Landsat-7 ETM+ akusisi 28 September 2002 dan 23 Januari 2005 dengan Path/Row 114/63. Dengan teknologi inderaja dan atau SIG didapatkan perubahan luas tambak, sawah dan penutupan/penggunaan lahan lainnya serta sebaran spasialnya di Kabupaten Pinrang seperti terlihat pada Gambar 1 dan Tabel 1. Pada tahun 2002, luas tambak 13.366, 1 ha dan pada tahun 2005 mencapai 14.569,2 ha. Sebaliknya, terjadi penurunan luas sawah di kawasan pesisir Kabupaten Pinrang dari 14.396,2 ha pada tahun 2002 menjadi 13.600,1 ha pada tahun 2005. Hal ini mengindikasikan terjadi konversi lahan sawah untuk penggunaan non-sawah, seperti lahan tambak yang cukup besar. Pada dasarnya, ketersediaan lahan secara total bersifat tetap di suatu wilayah, sehingga konversi suatu penggunaan lahan menjadi penggunaan lahan lain akan berdampak pada penurunan luas lahan yang dikonversi dan penambahan luas lahan hasil konversi. Konversi penggunaan lahan didorong oleh pertumbuhan penduduk, peningkatan pendapatan, kegiatan ekonomi dan migrasi dari wilayah lain maupun wilayah belakang kota di wilayah bersangkutan. Alih fungsi lahan terutama berkorelasi dengan laju pertumbuhan penduduk, kondisi ekonomi pertanian, level kemakmuran dari pembudidaya, tingkatan teknologi dalam produksi pertanian, variasi iklim dan faktor kebijaksanaan (Ostwald \& Chen, 2006; Quan et al., 2006). Khusus di Kabupaten Pinrang, alih fungsi sawah menjadi tambak sebagai dari keuntungan yang lebih tinggi

Tabel 1. Luas tambak dan sawah di kawasan pesisir Kabupaten Pinrang, Provinsi Sulawesi Selatan pada tahun 2002 dan 2005

\begin{tabular}{cccc}
\hline \multirow{2}{*}{ Tahun } & \multicolumn{2}{c}{ Luas tambak (ha) } & $\begin{array}{c}\text { Luas sawah } \\
\text { dari data inderaja } \\
\text { (ha) }\end{array}$ \\
\cline { 2 - 4 } & $\begin{array}{c}\text { Data } \\
\text { sumber lain }\end{array}$ & $\begin{array}{c}\text { Data } \\
\text { inderaja }\end{array}$ & $\begin{array}{c}\text { dan } \\
2002\end{array}$ \\
\hline $15.735^{*}$ & $13.366,10$ & $14.396,20$ \\
2005 & $15.735^{+}$ & $14.569,20$ & $13.600,10$ \\
\hline
\end{tabular}

Sumber:

": Anonim, (2002) ; + : Anonim, (2005) sebagai pembudidaya tambak daripada sebagai pembudidaya sawah (Sanusi, 2001).

Dari Tabel 1 terlihat bahwa ada perbedaan luas tambak pada tahun yang sama dari sumber data yang berbeda. Sebagai rekaman pantulan obyek dan fenomena bumi oleh sensor secara nyata menurut waktu, maka sajian data inderaja sangat mirip dengan kenampakan di lapangan. Hal ini merupakan nilai lebih dari analisis objek bentang lahan atau fenomena bumi melalui data inderaja. Selain itu, citra satelit tidak hanya mampu memberikan gambaran tentang jenis penggunaan lahan yang teridentifikasi, namun yang lebih penting lagi adalah penyebaran masing-masing jenis penggunaan lahan tersebut pada suatu kawasan. Informasi penyebaran ini penting dalam rangka pengembangan kawasan termasuk kawasan pesisir Kabupaten Pinrang. Penyebaran yang jelas akan memudahkan perencanaan dan pengembangan suatu kawasan. Selama ini inventarisasi jenis penggunaan lahan hanya mengacu pada jenis penggunaan lahan tersebut, namun belum berorientasi pada penyebarannya.

\section{PENENTUAN POTENSIAL LAHAN TAMBAK}

Data penginderaan jauh yang digunakan dalam penelitian ini adalah citra Landsat-7 ETM+ akuisisi 2005. Untuk mencakup lokasi penelitian dibutuhkan 1 scene citra Landsat yaitu: Path/Row 115/62. Penentuan luas potensial lahan tambak yang dilakukan seperti terlihat pada Gambar 2 yang merupakan lanjutan dari penentuan luas lahan tambak yang ada. Peta akhir penutup/penggunaan lahan di sekitar tambak yang ada digunakan untuk memprediksi potensi lahan tambak yang ada jika penutup/penggunaan lahan tersebut dikonversi menjadi tambak. Pemilihan peubah kunci yang tepat dapat memenuhi kebutuhan informasi akan wilayah pantai potensial untuk pengembangan kegiatan budidaya tambak khususnya sistem ekstensif dan semi-intensif. (Tarunamulia et al., 2008). Kemungkinan alih fungsi lahan tersebut dapat diprediksi dengan melibatkan beberapa peubah kunci pengembangan lahan tambak seperti elevasi lahan dan jangkauan pasang surut. Kegiatan penentuan luas potensial lahan tambak di Sulawesi Selatan telah dilaksanakan di Kabupaten Luwu Utara (Paena et al., 2008b), Kabupaten Luwu Timur (Hasnawi \& Mustafa, 2008) dan Sinjai (Tarunamulia et al., 2008).

Pada tahun 2005 luas tambak yang ada di Kabupaten Luwu Utara mencapai 7.838,94 ha, lebih luas dibandingkan dengan yang telah dilaporkan oleh sumber data yang lain yaitu seluas 7.628 ha (Anonim, 2005). Hasil analisis lain menunjukkan bahwa Kabupaten Luwu Utara memiliki potensi luas tambak yang memungkinkan untuk dibuka 


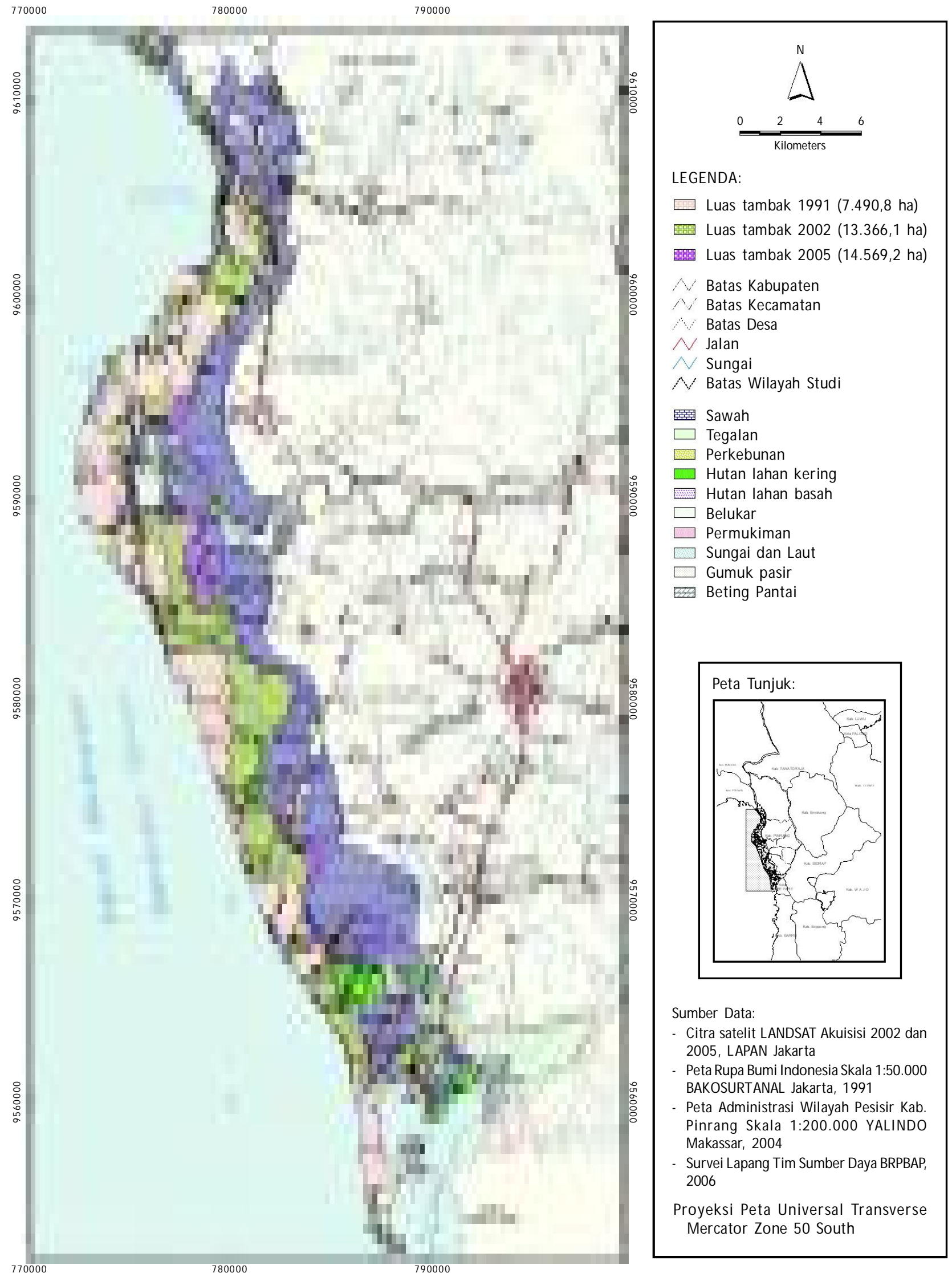

Gambar 1. Luas tambak di Kabupaten Pinrang, Sulawesi Selatan tahun 1991, 2002, dan 2005 (Paena et al., 2008a) 


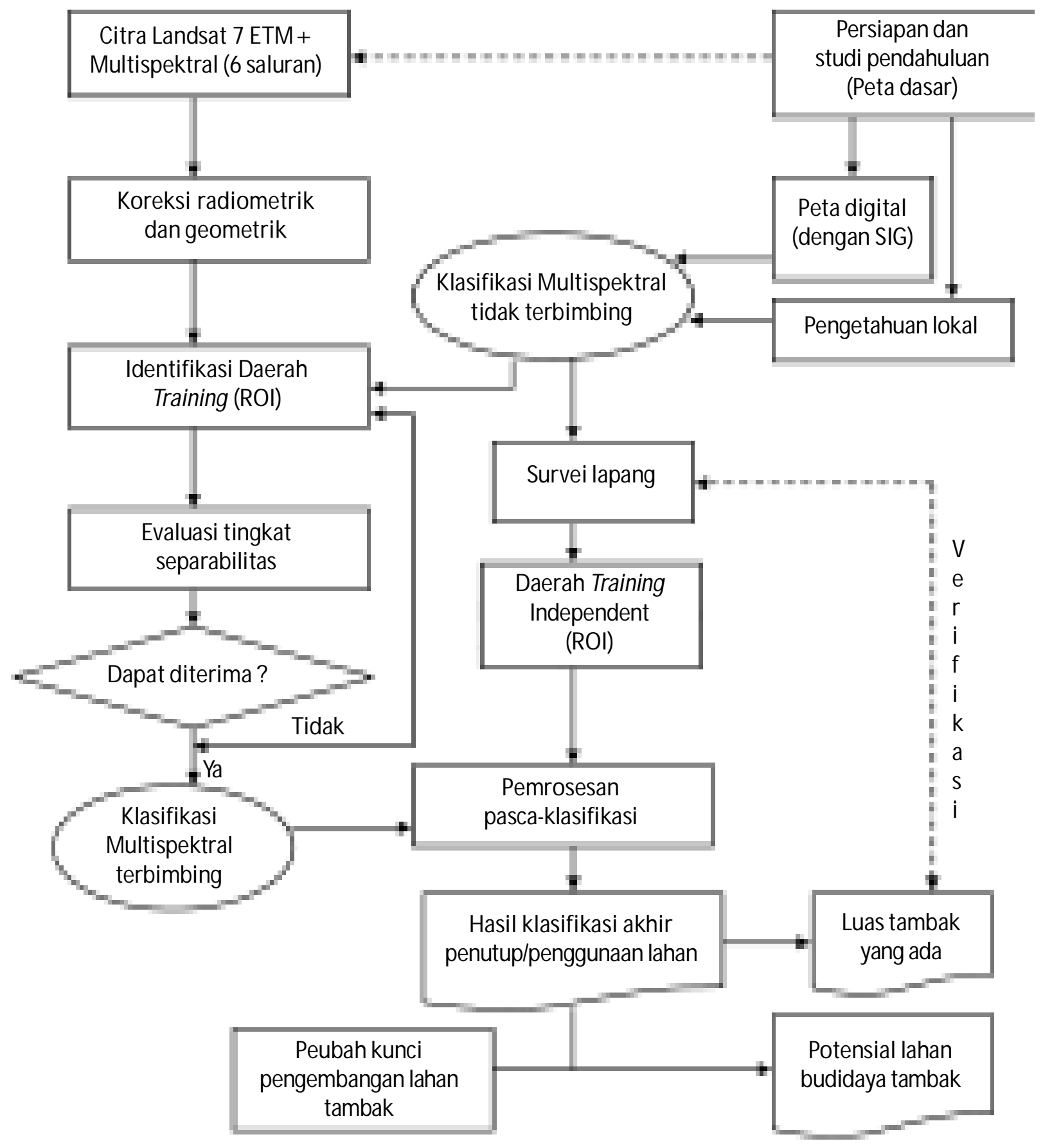

Gambar 2. Diagram alir dalam analisis spasial dalam penentuan luas dan potensial lahan budidaya tambak (modifikasi Tarunamulia, 2008)

menjadi tambak seluas $15.444,15$ ha, ini berarti luas tambak maksimum yang disarankan dapat dibuka hanya sampai pada batas luasan tersebut. Hal ini juga menunjukkan bahwa Kabupaten Luwu memiliki potensial lahan tambak seluas 7.605,21 ha. Dari luas lahan 15.444,15 ha sampai pada tahun 2005 baru dimanfaatkan 50,76\% dengan demikian lahan potensi yang masih tersedia sebesar 49,24\%(Gambar 3).

\section{PENENTUAN KESESUAIAN LAHAN TAMBAK}

Penentuan kesesuaian lahan untuk budidaya tambak di Sulawesi Selatan telah dilakukan di Kecamatan Malili, Kabupaten Luwu Timur (Pantjara et al., 2006), Kabupaten Pinrang (Mustafa et al., 2008), Kecamatan Balusu, Kabupaten Barru (Tarunamulia et al., 2008); Kabupaten Sinjai (Tarunamulia et al., 2008), Kecamatan 


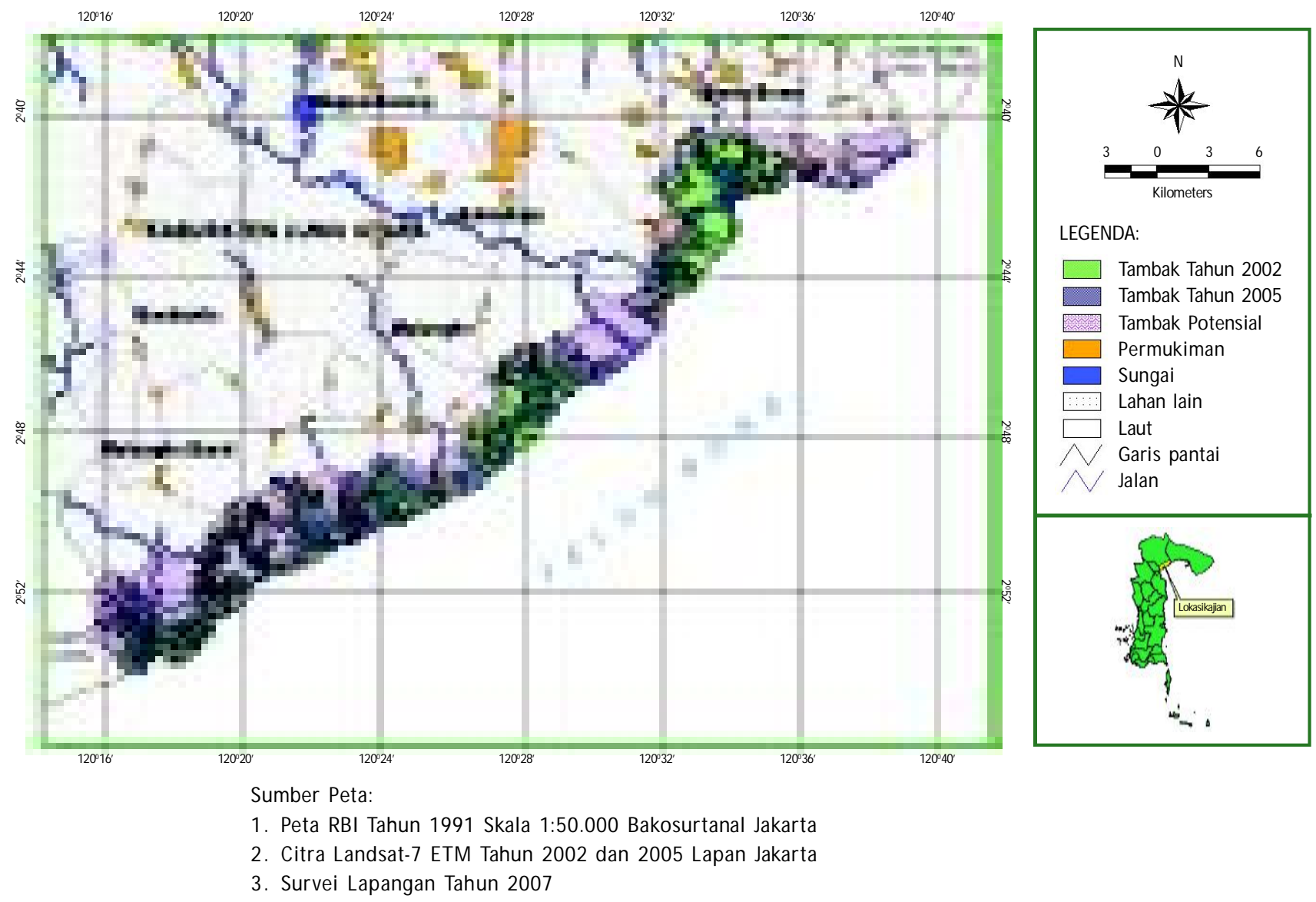

Gambar 3. Peta luas dan potensial lahan budidaya tambak di Kabupaten Luwu Utara Provinsi Sulawesi Selatan (Paena et al., 2008b)

Mangarabombang, Kabupaten Takalar (Utojo et al., 2008), Kabupaten Luwu Utara (Hasnawi \& Mustafa, 2008). Penentuan kesesuaian lahan untuk budidaya tambak di Kabupaten Pinrang dan Kecamatan Balusu, Kabupaten Barru diambil sebagai contoh.

Faktor yang dipertimbangkan dalam penentuan kesesuaian lahan budidaya tambak di Kabupaten Pinrang meliputi faktor-faktor hidrologi dan topografi lahan; kondisi tanah; kualitas air, dan iklim (Gambar 4). Kualitas air diamati pada musim hujan dan musim kemarau. Analisis spasial dalam SIG digunakan dalam penentuan kesesuaian lahan untuk budidaya tambak di Kabupaten Pinrang.

Data yang digunakan dalam penentuan kesesuaian lahan tambak di Kabupaten Pinrang adalah citra satelit dari Landsat-7 ETM+ akusisi 23 Januari 2005. Dari citra tersebut dapat diekstrak berbagai peubah yang menjadi peubah yang dipertimbangkan dalam kriteria penentuan kesesuaian lahan untuk budidaya tambak, seperti jarak sumber air, jenis penggunaan atau penutup lahan dan kondisi tanah serta jangkauan pasang surut.
Hasil analisis menunjukkan bahwa dari luas total tambak Kabupaten Pinrang 15.026,2 ha ternyata 7.389,4 ha tambak tergolong sangat sesuai (kelas S1), 1.235,1 ha tambak tergolong cukup sesuai (kelas S2), 3.229,0 ha tambak tergolong kurang sesuai (kelas S3), dan 3.102,7 ha tergolong tidak sesuai (kelas N) untuk budidaya pada musim hujan (Gambar 5). Sebagai faktor pembatas utama kesesuaian lahan tambak di Kabupaten Pinrang pada musim hujan adalah banjir di sekitar muara Sungai Saddang.

Pada musim kemarau, kesesuaian lahan aktual tambak di Kabupaten Pinrang menunjukkan bahwa 7.119,8 ha tergolong sangat sesuai (kelas S1), 4.908,6 ha tergolong cukup sesuai (kelas S2), 1.606,9 ha tergolong sesuai marjinal (kelas S3), dan 1.390,9 ha tergolong tidak sesuai (kelas N) (Gambar 6). Salinitas yang tinggi adalah faktor pembatas utama budidaya tambak pada musim kemarau. '

Peubah kunci lingkungan tambak di Kecamatan Balusu, Kabupaten Barru yang dianalisis meliputi areal konservasi, ketersediaan air laut dan penggunaan/penutup lahan di wilayah pantai (Gambar 7). Peta tematik untuk sub-model 


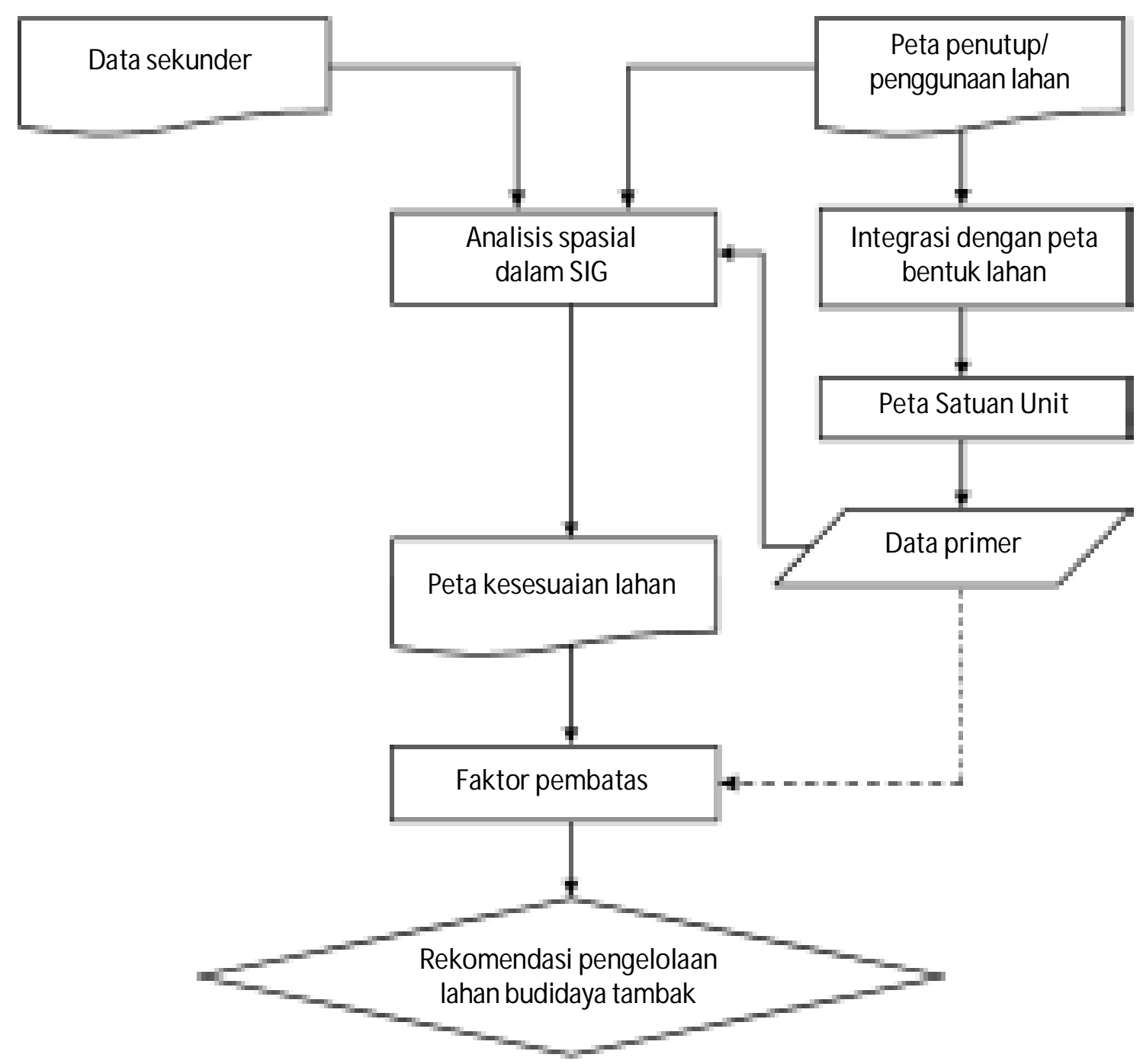

Gambar 4. Diagram alir analisis spasial dalam penentuan kesesuaian lahan untuk budidaya tambak (modifikasi Mustafa et al., 2007)

konservasi di wilayah pantai dibangun dari gabungan antara data pasang surut, peta rupabumi, dan peta lingkungan pantai. Pada peta tematik areal konservasi ini, selain jalur hijau/zona penyangga juga termasuk di dalamnya situs-situs sejarah atau hutan lindung jika ada. Peta kontur ketinggian lahan pantai yang diperoleh dari gabungan antara peta lingkungan pantai dan data elevasi digital dari "Shuttle Radar Topography Mission "(SRTM) (USGS, 2002) selanjutnya diklasifikasi berdasarkan jangkauan pasang surut (pasut) lokal (tidal range) untuk membangun sub-model ketersediaan air. Sedangkan untuk sub-model penggunaan lahan digunakan peta rupabumi dari Badan Koordinasi Survey dan Pemetaan Nasional (Bakosurtanal).

Output dari analisis ini mampu menghasilkan informasi spasial untuk berbagai kepentingan perencanaan dan penelitian. Luasan lahan termasuk sebaran geografis menurut tingkat kesesuaian sudah dapat diestimasi dibandingkan dengan metode lama yang utamanya diestimasi dari data statistik hasil sensus atau dari hasil analisis multi-kriteria. Untuk kebutuhan evaluasi kesesuaian penggunaan lahan, informasi dari output model ini sudah dapat dijadikan dasar untuk mengevaluasi status tambak yang ada, misalnya prediksi asal lahan yang dikonversi menjadi lahan tambak. Selanjutnya untuk kepentingan penelitian hasil analisis ini dapat dijadikan dasar untuk survai detail, antara lain dapat membantu dalam penentuan sebaran titik pengambilan contoh dan mengkonsentrasikan wilayah survai. Hasil analisis kesesuaian akhir berdasarkan peubah kuncil pada Gambar 8 menyerupai sebaran tambak yang ada dan kecenderungan pengembangan lahan tambak di wilayah studi. 
790000

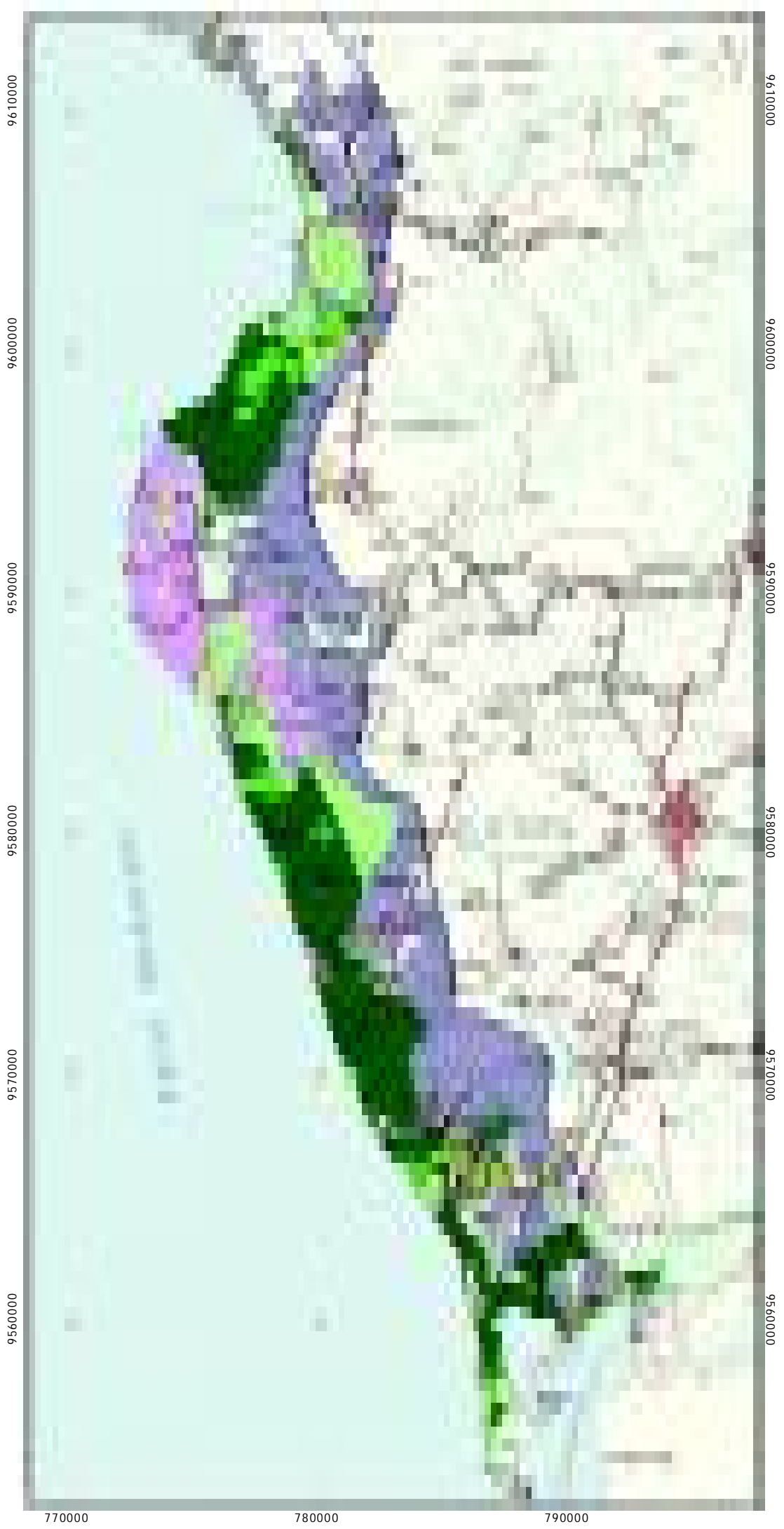

Kelas S1 (7.389,4 ha)

Kelas S2 (1.235,1 ha)

Kelas S3 (3.299,0 ha)

Kelas N (3.102,7 ha)

Batas Kabupaten

C Batas Kecamatan

Batas Desa

$\checkmark$ Jalan

$\sim$ Sungai

$\checkmark$ Batas Wilayah Studi

㯺 Sawah

Tegalan

Perkebunan

Hutan lahan kering

Hutan Iahan basah

Belukar

Permukiman

Sungai dan Laut

Hutan Iahan basah

Gumuk pasir

Beting Pantai

Peta Tunjuk:

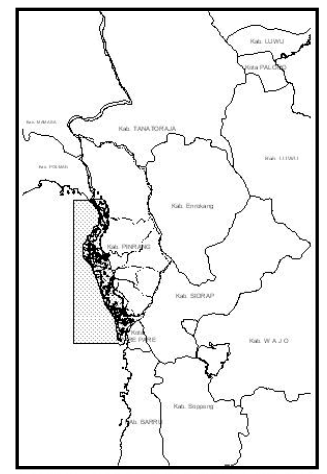

Sumber Data:

- Citra satelit LANDSAT Akuisisi 2002 dan 2005, LAPAN Jakarta

- Peta Rupa Bumi Indonesia Skala 1:50.000 BAKOSURTANAL Jakarta, 1991

- Peta Administrasi Wilayah Pesisir Kab. Pinrang Skala 1:200.000 YALINDO Makassar, 2004

Survei Lapang Tim Sumber Daya BRPBAP, 2006

Proyeksi Peta Universal Transverse Mercator Zone 50 South

Gambar 5. Peta kesesuaian lahan budidaya tambak untuk musim hujan di Kabupaten Pinrang Provinsi Sulawesi Selatan (Mustafa et al., 2008) 
780000

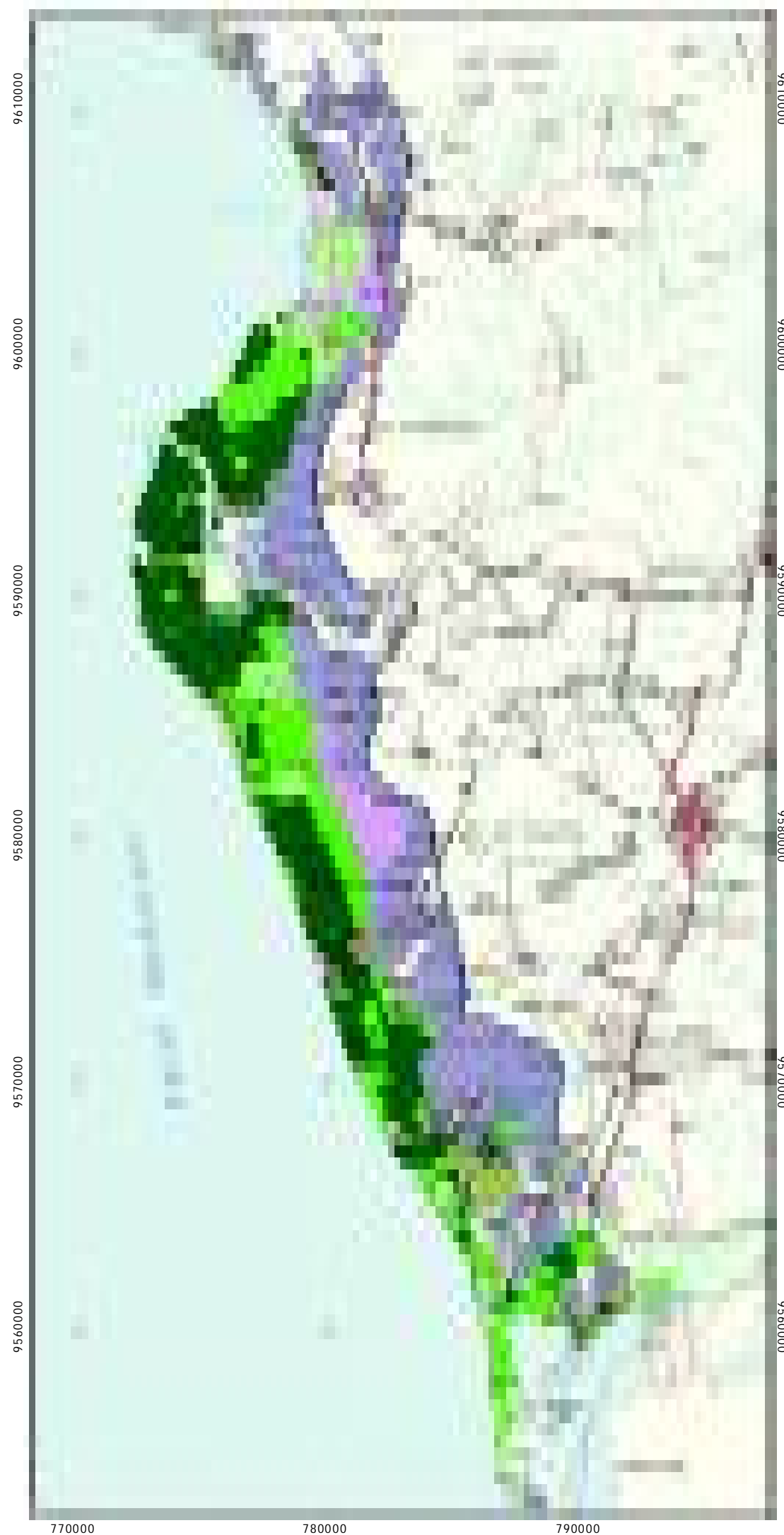

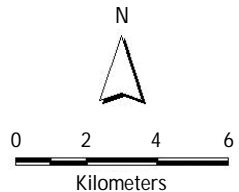

LEGENDA:

Kelas S1 $(7.119,8 \mathrm{ha})$

Kelas S2 $(4.908,6 \mathrm{ha})$

Kelas S3 $(1.606,9 \mathrm{ha})$

Kelas N (1.390,9 ha)

Batas Kabupaten

Batas Kecamatan

Batas Desa

$\checkmark$ Jalan

$\sim$ Sungai

$\checkmark$ Batas Wilayah Studi

譼 Sawah

$\square$ Tegalan

Hutan lahan kering

Hutan lahan basah

Belukar

Permukiman

Sungai dan Laut

Hutan Iahan basah

Gumuk pasir

Beting Pantai

Peta Tunjuk:

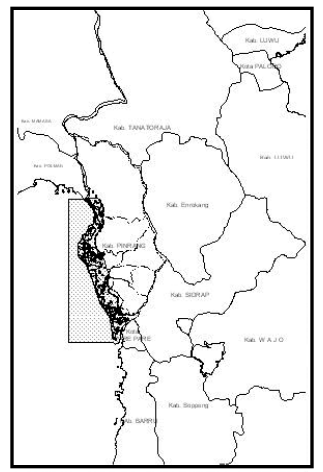

Sumber Data:

- Citra satelit LANDSAT Akuisisi 2002 dan 2005, LAPAN Jakarta

- Peta Rupa Bumi Indonesia Skala 1:50.000 BAKOSURTANAL Jakarta, 1991

- Peta Administrasi Wilayah Pesisir Kab. Pinrang Skala 1:200.000 YALINDO

Makassar, 2004

- Survei Lapang Tim Sumber Daya BRPBAP, 2006

Proyeksi Peta Universal Transverse Mercator Zone 50 South

Gambar 6. Peta kesesuaian lahan budidaya tambak untuk musim kemarau di Kabupaten Pinrang Provinsi Sulawesi Selatan (Mustafa et al., 2008) 


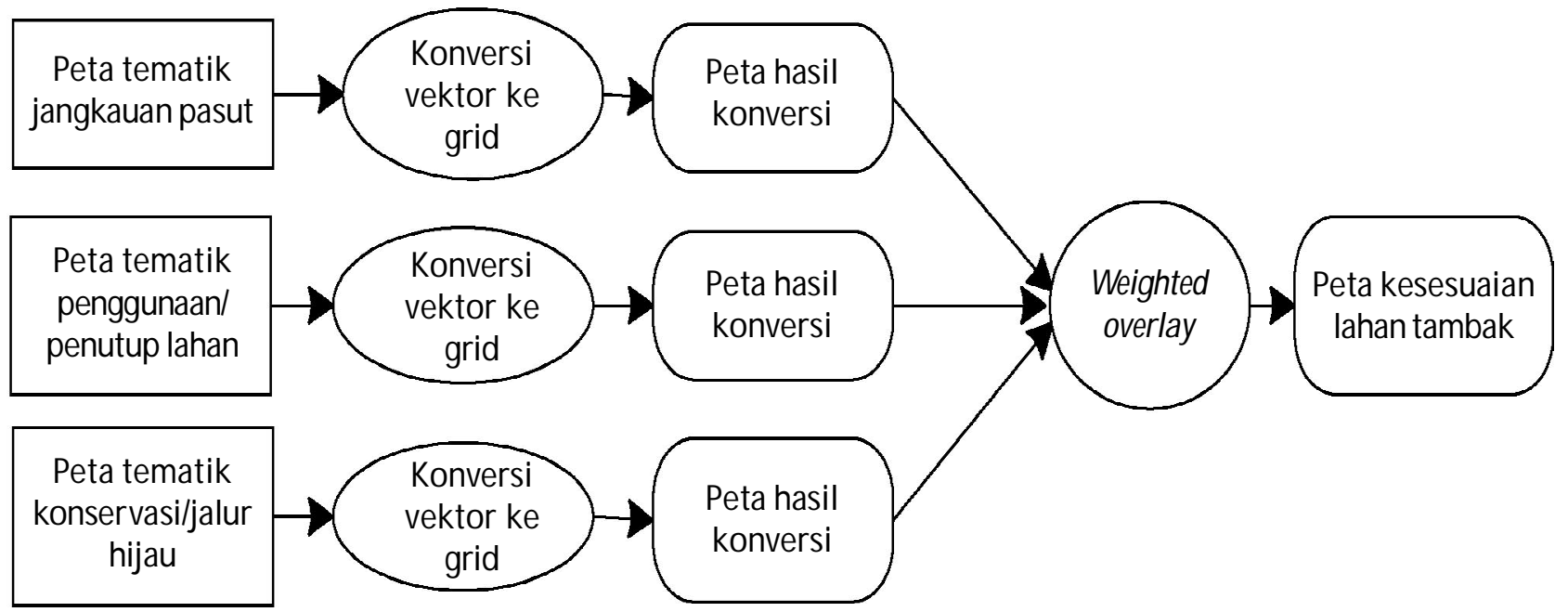

Gambar 7. Proses analisis kesesuaian lahan tambak dengan metode weighted overlay (Tarunamulia et al., 2008)

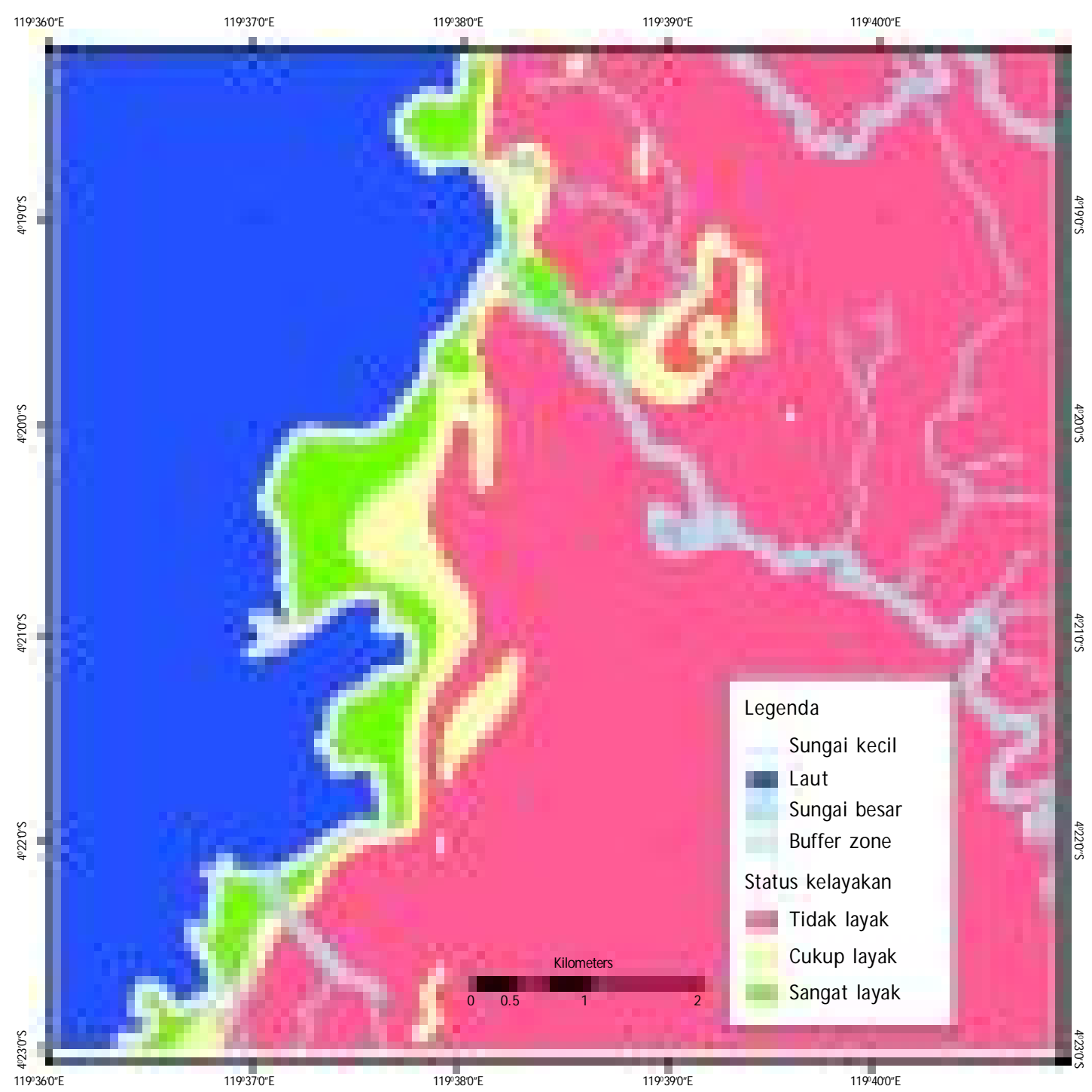

Gambar 8. Hasil analisis kesesuaian lahan skala semi-detail berdasarkan peubah kunci (Tarunamulia et al., 2008) 


\section{KESIMPULAN}

Hasil analisis data citra satelit penginderaan jauh dan atau radar yang dikombinasikan dengan sistem informasi geografis telah dimanfaatkan dalam kegiatan yang terkait dengan sumberdaya lahan tambak. Data hasil analisis citra satelit penginderaan jauh dan atau radar telah dimanfaatkan dalam penentuan luas lahan tambak yang ada, potensial lahan tambak dan kesesuaian lahan tambak di beberapa kabupaten di Sulawesi Selatan. Luas tambak di Kabupaten Pinrang pada tahun 2002 dan 2005 masingmasing 13.366,1 dan 14.569,2 ha. Dari luas total tambak Kabupaten Pinrang, 15.026,2 ha ternyata 7.389,4 ha tambak tergolong sangat sesuai (kelas S1); 1.235,1 ha tambak tergolong cukup sesuai (kelas S2); 3.229,0 ha tambak tergolong kurang sesuai (kelas S3); dan 3.102,7 ha tergolong tidak sesuai (kelas N) untuk budidaya pada musim hujan, sedangkan pada musim kemarau, kesesuaian lahan aktual tambak menunjukkan bahwa 7.119, 8 ha tergolong S1; 4.908,6 ha tergolong S2; 1.606,9 ha tergolong S3; dan 1.390,9 ha tergolong N. Kabupaten Luwu memiliki potensial lahan tambak seluas 7.605,21 ha.

\section{DAFTAR ACUAN}

Anonim. 2002. Laporan Statistik Perikanan Sulawesi Selatan. Dinas Perikanan dan Kelautan Provinsi Sulawesi Selatan, Makassar. $145 \mathrm{hlm}$.

Anonim. 2005. Laporan Statistik Perikanan Sulawesi Selatan. Dinas Perikanan dan Kelautan Provinsi Sulawesi Selatan, Makassar. $261 \mathrm{hlm}$.

Anonim. 2006. Statistik Perikanan Budidaya Indonesia 2005. Direktorat Jenderal Perikanan Budidaya, Jakarta. 116 hlm.

Anonim. 2008. Kebangkitan Budidaya Udang Windu di Sulawesi Selatan tahun 2008. Dinas Perikanan dan Kelautan Provinsi Sulawesi Selatan, Makassar. $12 \mathrm{hlm}$.

Danoedero, P. 2004. Klasifikasi penutup lahan secara rinci: Pengalaman dengan citra landsat ETM ${ }^{+}$dan Quickbird. Dalam: P. Danoedero (ed.), Sains Informasi Geografis: Dari Perolehan dan Analisis Citra hingga Pemetaan dan Pemodelan Spasial. Jurusan Kartografi dan Penginderaan Jauh, Fakultas Geografi, Universitas Gadjah Mada, Jogjakarta. hlm. 147-176.

Hasnawi \& Mustafa, A. 2008. Karakteristik dan kesesuaian lahan untuk budidaya tambak di Kabupaten Luwu Utara, Provinsi Sulawesi Selatan. Balai Riset Perikanan Budidaya Air Payau, Maros. $17 \mathrm{hlm}$.

Lo, C.P. 1996. Pengindraan Jauh Terapan. Diterjemahkan oleh: B. Purbowaseno. Penerbit Universitas Indonesia (UI-Press), Jakarta. $475 \mathrm{hlm}$.
Mustafa, A., Hasnawi, Paena, M., Rachmansyah, \& Sammut, J. 2008. Evaluasi kesesuaian lahan untuk budidaya tambak di Kabupaten Pinrang Provinsi Sulawesi Selatan. Jurnal Riset Akuakultur, 3(2): 241261.

Mustafa, A., Tarunamulia, \& Sammut, J. 2007. Klasifikasi kesesuaian lahan untuk budidaya tambak di Indonesia. Balai Riset Perikanan Budidaya Air Payau, Maros. $30 \mathrm{hlm}$.

Mustafa, A., Utojo, Hasnawi, \& Rachmansyah. 2006. Validasi data luas lahan budidaya tambak di Kabupaten Maros dan Pangkep Provinsi Sulawesi Selatan dengan menggunakan teknologi penginderaan jauh dan sistem informasi geografis. Jurnal Riset Akuakultur, 1(3): 419_ 430.

Paena, M., Mustafa, A., Hasnawi, \& Rachmansyah. 2008 a. Validasi luas lahan tambak di Kabupaten Pinrang, Provinsi Sulawesi Selatan. Jurnal Riset Akuakultur, 2(3): 319-328.

Paena, M., Mustafa, A., Hasnawi, dan Rachmansyah. 2008b. Validasi luas periodik dan penentuan luas potensi tambak di Kabupaten Luwu Utara Provinsi Sulawesi Selatan dengan menggunakan teknologi penginderaan jauh dan sistem informasi geografis. Jurnal Riset Akuakultur, 3(1): 137- 146.

Pantjara, B., Aliman, Mansyur, A., \& Utojo. 2006. Kelayakan lahan pertambakan di tanah sulfat masam Kabupaten Luwu Timur, Sulawesi Selatan. Jurnal Riset Akuakultur, 1(2): 281- 290.

Ostwald, M. \& Chen, D. 2006. Land-use change: Impacts of climate variations and policies among small-scale farmers in the Loess Plateau, China. Land Use Policy, 23: $361-371$.

Sanusi, A. 2001. Konversi Lahan Sawah Menjadi Tambak Ditinjau dari Pendapatan Petani. Tesis Magister. Program Pasca Sarjana Universitas Hasanuddin, Makassar. $74 \mathrm{hlm}$.

Tarunamulia. 2008. Application of Fuzzi Logic, GIA and Remote Sensing to the Assessment of Environmental factors for Extensive Brackishwater Aquaculture in Indonesia. Master of Science Thesis. The University of New South Wales, Sydney, Australia. 218 pp.

Tarunamulia, Mustafa, A., \& Sammut, J. 2008. Model analisis spasial kesesuaian lahan tambak skala semidetail berdasarkan peubah kunci tambak sistem ekstensif dan semi-intensif. Jurnal Riset Akuakultur, 3(3): 449-461.

USGS (United State Geological Survey). 2002. Shuttle Radar Topographic Mission (SRTM). http:// glcf.umiacs.umd.edu. Diakses 24/04/2007. 
Penentuan luas, potensi dan kesesuaian lahan tambak di Sulawesi Selatan ..... (Akhmad Mustafa)

Utojo, Mustafa, A., \& Hasnawi. 2008. Peruntukan lokasi budidaya tambak udang berwawasan lingkungan di Kecamatan Mangarabombang, Kabupaten Takalar. Balai Riset Perikanan Budidaya Air Payau, Maros. 24 hlm.
Quan, B., Chen, J.F., Qiu, H.L., Römkens, M.J.M., Yang, X.Q., Jiang, S.F., \& Li, B.C. 2006. Spatial-temporal pattern and driving forces of land use changes in Xiamen. Pedosphere, 16(4): 477-488. 